ROCZNIKI HUMANISTYCZNE

Tom LXVII, zeszyt 11 - 2019

DOI: https://dx.doi.org/10.18290/rh.2019.67.11-8

HALSZKA LELEŃ

\title{
EXPERIMENTING WITH HISTORIOGRAPHIC NARRATIVE AND GUIDEBOOK STYLE IN AN ORKNEY TAPESTRY BY GEORGE MACKAY BROWN
}

\begin{abstract}
A b stract. In An Orkney Tapestry George Mackay Brown creates a collage guidebook that exceeds the precepts of non-literary text and becomes an intermedial, literary guide to stories, traditions and identity of the archipelagic place. At the same time it is an experimental work that tests the concept of the duality of the story and the fable (understood in the sense proposed by Edwin Muir) that seems to Brown as redemptive in terms of culture preservation. Brown's semiotic and systemic choices seem to be aimed at countering the modern loss of meaning. The Orkney writer engages in dialogic reworking of the northern European tradition, striving for the heraldic, reader-oriented way or representation. The use of the technique of literary collage and fragmentary storytelling makes this book into an intermedial commentary on culture and its celebration.
\end{abstract}

Key words: George Mackay Brown; An Orkney Tapestry; guidebook features; literary collage; fragmentation; intermediality.

An Orkney Tapestry, the chief work of non-fiction (Baker 115) of George Mackay Brown (1921-1996) - a poet, short story writer, novelist and playwright of Scottish, Orkney identity - is a book that stands across the literary and non-literary medium. Rowena and Brian Murray in Interrogation of Silence: The Writings of George Mackay Brown state that this work is quite distinct because of its reader-oriented purpose: "Brown mediated historical and legendary stories for a modern society which he saw as over-committed to material gain" (118). Other Brown scholars note that it was written so as to "awaken Orcadians to the way things were going, and at the same time stir in them some pride in their roots" (M. Fergusson 199). However, looking at the text's semiotic features, its purpose seems to be much larger: inspiring

HalszKa Leleń, PhD - University of Warmia and Mazury in Olsztyn, Faculty of Humanities, Department of English Studies; address for correspondence — e-mail: halszka.lelen@uwm.edu.pl 
the reader to (re)connect with the cultural history and imagery of the northern archipelagic places and thus to (re)consider their own identity. Such qualities of the book evidently had their effect on Brown's contemporaries ("Fifty Years of 'An Orkney Tapestry"; Ferguson, Prologue xx).

The book was commissioned as a guidebook by Victor Gollancz publishers in 1967. However, it seems that Brown soon developed a different plan for it, intending to "create a work that would be at once a celebration and a jeremiad" (R. Ferguson, Wound 198). Some parts of An Orkney Tapestry work like the typical guidebook with historiographic focus, where one can see narrating history in the way that is organised by chronology, by "naming adversaries, establishing or imputing intentions and identifying obstacles and factors in overcoming them" (Fulda). One can also see an attempt at "selecting among the amorphous happenings of the past (as attested by sources) and configuring them historiographically as a consistent and hence understandable (hi)story" (Fulda). However, the narrative-dramaturgical method of telling the story in the historiographic method is redynamised by Brown through incorporating fragments of other literary texts, such as passages from his own and other people's poems, dramatic pieces, and short stories that begin functioning on the principle of juxtaposition through the technique of montage that draws attention to structure of the text. This is so in the description of the times of the Second World War, in the episode of the sudden German attack. What the reader gets is first a passage kept in the Present Simple tense that stresses the immediacy of bombing, and then a quote from another source, a poetic rendering of the situation by a fellow poet of an older generation:

Bombs fall everywhere; in the little hamlet of Birdge-of-Waithe was killed the first civilian, standing in his doorway. Ann Scott-Moncrieff wrote a poem about that night.

... They were

Flying doon the twa lochs

Following the sheen o' the water

- Dost thoo mind? Ah, that time o'night -

And they winned at last to the brig ${ }^{1}$ (Brown, Tapestry 9)

\footnotetext{
${ }^{1}$ A fragment of the poem "The Brig O'Waith” by Ann Scott-Moncrieff (1914-1943), Brown quotes sixteen lines of this poem of fifty-three lines, clearly aiming for selection of material as his omissions are marked with three dots.
} 
Brown quotes it, as the numerous other poems penned by himself and other writers that flock in the pages of An Orkney Tapestry, without providing the title or source. This fact, unthinkable in the contemporary times of protected author's rights, reveals his very purposeful strategy of having a compilation of real and imaginary Orkney voices that dramatise the momentary insights into shreds of experience and fragments of life - a technique typical for the aesthetics of a visual collage. What follows the poem is an instant shift of focus onto another place and time in archipelagic Orkney, the description of its largest town: "Kirkwall is a prosperous market town with about 5,000 people in it, a quarter of the total Orkney population. The town features many fine old buildings, one of them a jewel of great price: Saint Magnus Cathedral" (Brown, Tapestry 10).

With such shifting of types of texts and kinds of insight, Brown seems to aim at the "establishment of new networks of significance," typical of the device of collage (Thomas 80). These networks affect the northern poetics of verbal restraint used in the book and give it a powerful sign-oriented effect coming from multivocality. The necessity of confronting figures and voices, with their distinct stances, attitudes and perspectives is perhaps most visible in the separate text of a short story which constitutes the sub-chapter titled "The Ballad Singer." Its composition relies on constant shifts between narrative frame and the quoted text of a long ballad, which results in a fragmentary intermedial kind of text. The short story opens in medias res with multi-sensory detail that creates the effect of verisimilitude. The description renders the starting moment of singing of a traditional Scottish/Orkney ballad of Lady Odivere. The narrative focuses on various personal reactions of the gathered men and women to the performance which provokes them to reflect on themselves. The descriptions of their behaviour as well as their thoughts, presented with focalised third-person narration, are elliptical, and they are consistently broken with quotes in lengthy fragments of the versified text. While the ballad is traditional in style, each part of the prose text coming in between the ballad sections is made unique to imply more than is directly said about the character. For example, the peasant girl reacts in the way which points to her irregular situation in the court:

Already little Alysoun, the earl's latest mistress, looked about her with a white pinched face. How strange it was (thought Alysoun), the tide of lust and liking, with its ebb and flow like the sea! A girl that had been cold and still as a pool all her life - one day a glance or a word made her lance and burn like fire. Alysoun knew exactly how it was with Lady Odivere. (Brown, Tapestry 154). 
The narrative focus is not only on the ballad but also on its impact seen in its reception. The text's composition is dynamic as it relies on giving the motley picture of Orkney characters shown in various stages of self-insight. The reader is granted only some fragmentary glimpses of their life, their weaknesses and aspirations, being thus forced to develop the complete view of the community as the story progresses, which also foregrounds the process of characterisation itself.

As the body of Brown's main text is consistently infused with poems and dramatic pieces, this technique activates the reader to make sense of the intrusions, and to (re)connect them. The choice of the quoted fragments reveals the aesthetic dominant. This is made clear in the consistently used binary principle of selection and combination. All through the book, the regular features of a guidebook are broken by literary texts that enhance $A n$ Orkney Tapestry with their distinct epic, lyrical and dramatic patterns, provoking the reader not just to make sense of the whole but to react to its making. The intermedial intrusions of the other kinds of literature-prose, poetry and drama-that break the flow of historic narrative evoke the readerly expansion of focus from what the text tells (proper of the historic non-fiction but also of the epic kind of literature), to what the text expresses (proper of the poetic kind) and ultimately what the text presents (characteristic of dramatic texts' presuppositions) (Krajka and Zgorzelski 108).

This immensely varied text is characterised by a kind of double aesthetic and docudrama focus that is very dynamic in effect, as well as having a powerful narrative orientation. On the one hand, the reader gets some quasimimetic vignette scenes of ordinary, inconspicuous life; on the other hand, they are exposed to the intermedial styles that ensure multiple semiotic aesthetic transpositions of some culturally seminal moments and elements.

The islands seem to get the face of typical local people and their distinct voices through Brown's use of dramatic and poetic narrative style. The passage describing Orkney character types who are gradually disappearing is followed by seven dialogic flash stories, coming in between the main narrator's commentaries. They are brief, fragmentary glimpses into some distinct aspects of Orkney reality across history, where people have to react to peculiar situations of change, illumination or reversed expectations. The first fragment is an instant of the dialogue between an island minister and an old man who has just lost his wife: 
"Ah," said the Hoy minister, consoling an eighty-year-old crofter whose wife had just worn away_-"ah, now, Jacob, look at it this way-the Lord hath given and the Lord hath taken away..."

Jacob considered for a while.

"Weel," said he at last, "what could be fairer nor that?" (Brown, Tapestry 10)

These dramatic short short stories, of five up to ten sentences, present some salient Orkney characters and their typical ways of acting. People are sometimes given proper names. They are shown at the moment of coming to terms with some loss or facing the figure of the Other-someone from the outside or from higher social strata-which provokes their reaction.

The orientation is on showing characteristic figures and their voices, thus employing the device of prosopopeia. The technique of using other people's voices, as Małgorzata Grzegorzewska points out in "The Voice of the Other: The Figure of Prosopopeia in Medieval and Early Modern English Religious Poetry," ${ }^{2}$ helps the reader interpret the text through its coming alive. The scholar draws attention to the fact that this is the core of what Mikhail Bakhtin called the dialogic effect of literature. This effect shows not just in the structure of the text, although it surely appears there, but it is also present in the reader's projected reaction. It makes the reader impose their perception of the voices upon the text, which in turn makes the text gain some personalities, some faces and/or some masks (Grzegorzewska 14). Brown's focus is evidently on constant collision of voices, faces, masks and mouths that create the motley collage of Orkney culture at all times (Grzegorzewska 234). The writer seems to rely on this technique to create the impression of a contact with a gallery of faces and figures. The dramatic use of character voices at times subdues the dominant implied author's voice, leaving space for the readerly engagement in the process of interpretation. This allows the reader to grasp the paradigms of Orkney northern restrained communication and the stoical worldview, or rather to feel them through the narrative equivalents of first-hand experience.

Construing the narrative is also thematised in the book. It is represented as a process of historical (re)construction that allows for perception of figures against their cultural landscape. The narrator admits directly, in a selfreferential way, that this fictionalising (or, more precisely, storytelling) the past is his objective. He points out that the characters can only be imagined through the story. They can be regained, so to speak, through the effort of

\footnotetext{
${ }^{2}$ Original Polish title: Trop innego głosu $w$ angielskiej poezji religijnej epok dawnych.
} 
cultural insight that is impossible without artistic creation since they are not preserved through any artefacts, not even in legends:

The first Orkney peoples can only be seen darkly, a few figures on a moorland against the sky, between twilight and night. They are beyond the reach of legend even. Archeologists describe a Mediterranean folk who committed themselves to the sea. They steered their boats through the Straits and northwards, keeping close inland (for they could not trust such frail vessels far out, with their precious cargo of tribal symbols and secrets, stock, seed, nubile girls), all the way up the coastline of Spain and France. [...] Beyond the savage bulk of Cape Wrath there was empty ocean, until in a summer dawn they saw the Orkneys like sleeping whales. There they made landfall. (Brown, Tapestry 17, emphasis added)

The implied author represents his role here as a sort of literary-cultural anthropologist working with the semiotic aspect of cultural space that (1) he helps the reader to read through archeological-anthropological clues, and (2) he makes the reader participate in by means of the strategic storytelling oriented on contact through the techniques of narrative immediacy. In his stories Brown (re)discovers and envisions the structures of Orkney history that are beyond the reach of a historian working through traditional means of historic research.

Showing the story of the place in an intermedial aesthetic way, Brown is most interested in overcoming the limitations of history, along with its methods. Imagination is to compensate for what history cannot decipher, failing to read the palimpsestic human traces to be found in the land:

Hardly a thing is known about these first Orkneymen (if they were the first Orkneymen) apart from the monuments they left behind them, the huge stones of Maeshowe and Brodgar, and the pastoral village of Skara Brae in the west. History can tell nothing; not a word nor a name comes out of the silencethere are a few ambiguous scratches on a wall at Skara Brae. We wander clueless through immense tracks of time. Imagination stirs about a scattered string of bone beads found in Skara Brae. Did the girl have no time for adornment when a westerly gale choked the doors with sand; or did sea raiders tear them from her neck? (Brown, Tapestry 18, emphasis added)

As "history can tell nothing" about the stone-age Orkney-evoked through the settlement of Skara Brae, the burial chamber Maeshowe, and the stone ring of Brodgar - the attitude of historiographic supposition enriched by storytelling has to be adopted by a non-historian interested in the place. The 
only help is the re-creating power of the writer who can give clues about the people connected with the places.

After such an open statement of his method, Brown instantly goes on to give the example of an Orkney man who understood these issues. He remembers the figure and voice of his artistic mentor, a Scottish modernist poet, Edwin Muir (1887-1959). Rather than describe him, Brown chooses to show his friend's creative method through quoting a fragment of "The Ring" by Muir. The first stanza of the poem takes the reader back to the time beyond the reach of history:

Long since we were a family, a people,

The legends say; an old kind-hearted king

Was our foster-father, and our life a fable. (Muir "The Ring", qtd in: Brown,

Tapestry 18, emphasis added)

The choice of the passage shows how much Brown is interested in creating a story that is identity-oriented through its mythopoeic focus. Sabine Schmid notes: "Brown not only embraced Muir's distinction of the Story and the Fable but also the belief that the fable is repeated over and over again, implying that there is an eternal recurrence or a perpetual re-enactment of events and characters" (63). She sees this method at work in Fishermen with Plougs but in fact it permeates An Orkney Tapestry as well, which is full of foregrounded hermeneutic dualities. Further on in the text Brown draws attention to the peculiar quality of imagery in Muir's poetry which leads him to find its seeds in the landscape of Orkney:

What fed Edwin Muir's heart and mind with such archaic pellucid imagery? There were withered sandstone emblems over the lairds' and merchants' gates. But I think it is more the look of the islands that suggest heraldic stillness and a hoarded symbolism - quarterings on the hill, pasture and meadow and cornfield, a slow change throughout the year; and, older still, the great shield of the sky swarming with azure and gules, and clouds like fabulous beasts rampant. (Brown, Tapestry 19, emphasis added)

Detecting heraldic quality in the landscape, Brown establishes key semiotic factors for encoding and reading the salient patterns of time and space. Heraldic sensitivity is something that has become a staple feature mentioned 
in receptions of Brown's poetry by scholars and readers. ${ }^{3}$ It is also the device that he very consciously and consistently uses in An Orkney Tapestry. As the text demonstrates, Brown questions the style and the alleged factual information of a guidebook or even of a pseudo-historic book. He steers clear of consistent fact-oriented historiographic focus, although he at times yields to it, as in his commentaries on progress. His fragmentary, collagelike and syncretic technique is aimed at producing figurative representation of a multi-faced Orkney fable with heraldic figures and symbolic stories that exert an influence deeper than the impact of language alone. Ultimately he concentrates on showing time, place and human figures united through action, entwined in the most basic quotidian activities, and communicating the metaphysical as well as spiritual senses.

The fullest and most varied sample of the above method comes in "Rackwick," the second chapter in An Orkney Tapestry. It gives the reader a varied - and technically very syncretic - insight into history understood as aesthetic (hi)story or hi(gh)story, the fable which Brown regarded as the core of Orkney and of any human experience:

Another road branches westward between the hills, into utter desolation, a place of kestrels and peatbogs. One thinks of the psalmist and his vale of death. After five miles the road ends abruptly at a glint of sea and the farm of Glen. The dark hills are still all round, but they hold in their scarred hands a green valley. This is Rackwick. The bowl is tilted seawards - its lip is a curving bay, half huge round sea-sculptured boulders, haf sand. Out in the bay, like guardians, stand two huge cliffs, The Sneuk and The Too. (Brown, Tapestry 27)

The description of the place is introduced through a vertical and horizontal conception of space, both evocative of figurative associations-cliffs like guardians and the valley like a bowl with a lip reaching into the ocean. The importance of this place is thus highlighted by its liminal physical aspect, its position in-between the elements, and by the striking imagery. Its physical position between the towering hills is further extended into a prominent cultural association-it is compared to the valley of death from an unidentified Psalm. The Biblical source as the hypotext (Genette 5) for the passage emphasises Brown's attitude revealed in An Orkney Tapestry, that is, the double poetic-narrative focus on not just the existential but also the

\footnotetext{
${ }^{3}$ Seamus Heaney wrote in a review of Brown's poetry: "Mackay Brown's imagination is heraldic and formal [...]. I have never seen his poetry sufficiently praised" (qtd. in "George Mackay Brown: 1921-1996”).
} 
spiritual and implicitly metaphysical aspects of rural existence. The Biblical symbolic space works to modify the understanding of the Orkney places and to transpose their significance into figurative importance. The hardship of life is indicated through the abandoned quality of the place that gradually turns into ruin. It gains some sort of elegiac quality, with particular sensitivity to the symbolic signs of the lost struggle for survival in the natural conditions: ruined houses, broken windows and roofs, cold hearths:

The floor of the valley and its fertile western slope are littered with half-ruined crofts - the windows blind, the roofs fallen in, the hearth-stones forever black. Here and there among the barns and outhouses are stone jars, rusted ploughs, broken cups. There was abundant life in Rackwick once; the life ebbed out rapidly through some flaw; the place is full of the ghosts of the centuries. (Brown, Tapestry 28, emphasis added)

The image of ruin paradoxically leads Brown to the description of the past way of life. Immediately after this evocative rendering of a contemporary waste $l \mathrm{and}^{4}$, a favourite modernist motif, there comes a gap of a couple of lines that signals a narrative shift. After that the text moves back to the time of the first advent of human civilisation into the valley. The prose regularly gives way to fragments of poetry which transpose the experience described in the narrative through the lyrical medium. All the time the focus is on the principle of repetition and change:

Time and chance happened to the valley. Changes came in the way of progress that were considered to be good. [...] This reading of newsprint was thought to be a great advance on the chanting of old winter stories. (Brown, Tapestry 46)

We can see here the returning motif of the issue of loss of traditional storytelling. Yet another time it is identified as central in what happened to the community. This is a self-referential element of the whole book and it is also represented in its formal aspect. An Orkney Tapestry encodes the traditional stories and genres into its making to counteract this effect of the death of stories that brings the demise of the community. This explains the purposeful, reader-oriented strategy of mixing stylistic techniques throughout the whole text.

\footnotetext{
${ }^{4}$ This was indeed the state of the valley at the time of An Orkney Tapestry composition. However, the impact of the book was so strong that now the place has become a sort of artists' recess, becoming an Orkney favoured retreat for people seeking a creative or existential hermitage.
} 
Brown also admits the effort of trying to reach some clear view of the cultural landscape and its people when describing St Magnus. He rejects the traditional petrified perspectives so as to be able to see the man. He shows his endeavour as complicated by the necessity of using some not necessarily reliable sources: "We cannot get a clear picture of the man because his monkish biographer has smudged the outline with conventional pious platitudes" (71). This is followed by quoting some imaginary chronicle sources where Saint Magnus's description is much distorted, being idealised through the excessively lengthy list of overbearingly positive epithets: "[...] a most outstanding man, tall, virile, with a vivacious expression, virtuous in his doings, lucky in war, wise, witty ..." (Brown, Tapestry 71). The quotation from the chronicle concludes in three dots, suggesting an incomplete list of virtues. However the voice of the main narrator instantly denies or reinterprets the information provided by the medieval source: "In fact the bones of Magnus in Kirkwall Cathedral show him to have been a rather small man, not tall as the scribe insists. The complete portrait therefore falls apart, like a loose thread unravelling a badly-knitted garment" (Brown, Tapestry 72).

The presentation of the saint and his early life is suddenly broken to ask a question about the larger social panorama of the islands: "What kind of a community lived in Orkney at the beginning of the twelfth century?" (Brown, Tapestry 74). This question is answered through the description of the island women. The rendering of social panorama clearly draws attention to its textuality through organising units of discourse on a double and treble basis. This is visible for example in the use of the conjunction "and" as well as multiple enumerations:

\footnotetext{
The island women must be mentioned too-Hild and Gerd and Biorg-who lived between the well and the fire. Busy with spinning, grinding, churning, they turned perpetual wheels of wool and stone and milk. They obeyed implicitly the rhythms of fruition in the fields and in their own bodies, the great wheels of moon and sun. (Brown, Tapestry 76, emphasis added)
}

The rhythms of human life correspond to the pattern of nature. Turning the wheels at labour is repeated in the movement of moon and sun. Such patterns of figurative representation work on a large scale as well in the whole poetic guidebook. The text reveals its highly wrought stylistics by relying on extended metaphors, such as the metaphor of a garment used to represent society, or the metaphor of weaving as standing for culture. This 
corresponds to the idea of multistrand fabric that is used as the central compositional principle of the whole text, marked upfront with its selfreferential title:

In a wholesome society the different estates are stitched together in a single garment: the warmth and comfort and well-being of the people, a symbol too of their identity and their ethos. Their language, their work, their customs, all they think and do and say, decide the style and cut of the coat. The simplest bit of social intercourse - a conversation at a cross-roads, the selling of a pig, a kiss in the darkness-puts in another stitch, does its bit in holding the tribe together and ensuring its survival. (Brown, Tapestry 76, emphasis added)

Representing the act of stitching together of the garment with different aspects of community interaction, including the verbal one, evidently corresponds to the collage method of the whole text composition. This is the context for introducing the detailed description of the martyrdom of Saint Magnus and its effect, which is related using saga plot $^{5}$ and sections of dramatic dialogue. At the same time there is deep awareness of the patterns of history:

Yet all through history the shuttles are flying, perpetually, secretly, silently. The wedding garment, the shirt of invisible fire, is being woven - in little islands where the brothers plough and fish and pray; in lonely oratories; in great churches from Galway to Byzantium; and now, again, on a martyr-stone in a cold northern island. (Brown, Tapestry 84)

We can see here a distinctly poetic diction, representing the flow of history and culture in extended figurative terms of cloth weaving. The system of multiple parallelisms and echoes is at work in the disparate parts of the text.

What follows these ruminations on the sense of St Magnus's sacrifice is pointing out its dramatic potential and promising the reader there will be written a play about it one day. ${ }^{6}$ The one-act play that is offered immediately after this statement is a sample of Brown's capability as a symbolic regional

\footnotetext{
${ }^{5}$ Brown openly admits using Orkneyinga Saga for his descriptions of The Battle of Clontarf, St Magnus martyrdom and the Viking crusade. He also directly states that the sixth part of $A n$ Orkney Tapestry titled "The Watcher" and subtitled "A Play" is a rewriting of Leo Tolstoy's short story "What Men Live By" (Brown, For the Islands I Sing 170-171).

${ }^{6}$ Compare discussion of later use of the motif in L. Bicket "The Looms of History." She also points to John's Gospel as the source of the association of Saint Magnus death with the motif of spinning.
} 
dramatist. "Jock and Mary" that concludes the "Martyr" subchapter of An Orkney Tapestry uses the verisimilar but also somehow abstracted picture of a pair of beggars on a country road to offer a poetic, metaphorical commentary on the fate of the Everyman type of person. The two vagabond tinkers travel to the tomb of St Magnus for the sake of Mary. She is troubled by her blindness but she does not believe this can help. The dramatic rendering of the conflicted attitudes of the couple brings an insight into the human condition with its troubles and tensions. The setting introduced at the opening of this play represents an indefinite (but also recognisable Orkney) rural space at some generalised cyclic time:

Jock and Blind Mary are on the road, By hills, lochs, crofts, peatbogs, fishing boats, howes, hamlets, kirks, wells they go all the year round, from leaf-andlamb, into the bronze of harvest, and into white winter, and beyond it, into a new light. (Brown, Tapestry 87)

We can see in the play Brown's creative transposing of the pattern used by Samuel Beckett in Waiting for Godot. The core of Beckett's plot motivation is evidently present here: the two beggars are on the road because of their desire to move on and to understand, both of which they find difficult:

MARY: What's at the end of this road?

JOCK: The Birsay kirk.

MARY: A kirk? What are we going to a kirk for? There's nothing to eat in a kirk.

$\mathrm{O}$ no, I'm going to no kirk. I assure you for that. Kirk indeed.

JOCK: Come on then.

(They trudge on.) (Brown, Tapestry 87)

Being offered basic care like food and a cure are also cental here. However, whereas in Beckett's disillusioned theatre-of-the-absurd world view there is no hope only stagnation and paralysis, in Brown's system of signification, the potential for change and cyclic progression is dominant, without losing the perspective on human weakness. The solution is the spiritual aspect which in Beckett is strongly present as well but is devoid of causative force. In Brown's play the resolution is positive: in the end Mary regains sight. The common-place style of the community drama is counterbalanced by the extensive commentaries from the implied author coming in parenthetical, italicised intrusions. The grand philosophical style of these passages reveals the wish to explain the life of a universally conceived individual who is part of the larger scheme of the whole creation: 
(Into the hands of every unborn soul is put a lump of the original clay, for him to mould vessels - a bowl and a lamp-the one to sustain him, the other to lighten him through the twilight between two darknesses, birth and death. He refreshes himself, this Everyman, with mortal bread; he holds his lamp over rut and furrow and snow and stone, an uncertain flame. Now and then the honey of a hidden significance is infused into his being. [...]) (Brown, Tapestry 98-99).

Brown voices here his spiritual and metaphysical understanding of existence, enhanced by the use of Biblical symbolism of quotidian rural elements like clay, lamp, bread and stone. The natural rhythm of things in human life, represented by Orkney life, is shown to consist of work, death and regeneration.

In An Orkney Tapestry the implied author's choices are oriented toward (re)creating the mythopoeic roots of the palimpsestic present. The reader is invited to make sense of an intermedial collage of stories: (1) to appreciate smaller narratives, shaped and affected by some aesthetic choices which foreground particular signs and symbols, and (2) to allow to navigate-that also means to recreate-the relations between them. Brown uses the method which is technically postmodern but, at the same time, is not congruent with the postmodern way of thinking. On the one hand, Brown attempts rehistoricization through mininarratives; on the other hand his creative method reveals his searching for Muir's Fable and for the ultimate truth questioned in postmodernism. The distinct method, not congruent with the dominant postmodern ideology of his times that is visible in Brown's attitude to history is represented through the composition of An Orkney Tapestry based on reenvisioned, mediated fragments of (hi)stories of some insignificant events, little people and peripheral places that are granted universal significance. One can associate Brown with the modernist allegiance to seeing the unity and recurrence of pattern.

\section{WORKS CITED}

Baker, Timothy C. George Mackay Brown and the Philosophy of Community. Edinburgh UP, 2009. Bicket, Linden. "The Looms of History in George Mackay Brown's Literary Landscape." eSharp. Special Issue: Spinning Scotland: Exploring Literary and Cultural Perspectives, 2009, pp. 5-17. https://www.gla.ac.uk/media/media_128986_en.pdf. Accessed 22 Apr. 2019.

Brown, George Mackay. An Orkney Tapestry. 1969. Quartet Books, 1973.

Brown, George Mackay. For the Islands I Sing: An Autobiography. John Murray, 1997.

"Fifty Years of 'An Orkney Tapestry'." Archives @ University of Edinburgh. http://libraryblogs. is.ed.ac.uk/edinburghuniversityarchives/. Accessed 1 Apr. 2019. 
Genette, Gerard. Palimpsests: Literature in the Second Degree. University of Nebrasca Press, 1997.

"George Mackay Brown: 1921-1996." Poets. Poetry Foundation. https://www.poetryfoundation.org/ poets/george-mackay-brown. Accessed 20 April 2019.

Grzegorzewska, Małgorzata. Trop innego głosu w angielskiej poezji religijnej epok dawnych [The voice of the other: The figure of prosopopeia in medieval and early modern English religious poetry]. Universitas, 2011.

Fergusson, Maggie. George Mackay Brown: The Life. John Murray, 2006.

Ferguson, Ron. George Mackay Brown: The Wound and the Gift. Saint Andrew Press, 2011.

Ferguson, Ron. Prologue. George Mackay Brown: The Wound and the Gift, by Ferguson. Saint Andrew Press, 2011, pp. xix-xxxiv.

Fulda, Daniel. "Historiographic Narration." The Living Handbook of Narratology, edited by Peter Huhn et al., Hamburg University, revised version, 7 March 2014. http://www.lhn.unihamburg.de/node/123/revisions/314/view.html. Accessed 14 Apr. 2019.

Krajka, Wiesław, and Andrzej Zgorzelski. "Genological Relationships." On the Analysis of Literary Text. Translated by Artur Blaim, Państwowe Wydawnictwo Naukowe, 1984, pp. 105-167.

Schmid, Sabine. "Keeping the Sources Pure": The Making of George Mackay Brown. Peter Lang, 2003.

Thomas, Jean-Jacques. "Collage/Space/Montage." Collage, edited by Jeanine Parisier Plotter, New York Literary Forum, 1983, pp. 79-102.

\section{EKSPERYMENTY Z NARRACJĄ HISTORIOGRAFICZNA \\ I STYLISTYKĄ PRZEWODNIKA TURYSTYCZNEGO \\ W AN ORKNEY TAPESTRY GEORGE'A MACKAYA BROWNA}

Streszczenie

George Mackay Brown w utworze An Orkney Tapestry wykorzystuje formułę kolażu do modyfikacji konwencji przewodnika. Tekst ten przekracza ramy utworu nieliterackiego i staje się literackim przewodnikiem po świecie opowieści, tradycji i tożsamości miejsca o naturze archipelagu. Jednocześnie jest to utwór eksperymentalny, która testuje koncepcję dualizmu opowieści i bajki/mitu ("the story and the fable" Edwina Muira). Ta opozycja jest przez Browna wskazana jako czynnik ocalający kulturę. Brownowskie wybory semiotyczne i uporządkowania systemowe zdają się ukierunkowane na przeciwdziałanie współczesnej utracie sensu. Poprzez heraldyczne, zorientowane na czytelnika techniki reprezentacji Orkadyjski pisarz podejmuje wysiłek dialogicznego odtwarzanie północno-europejskiej tradycji. Zastosowanie technik literackiego kolażu i fragmentaryczności w sposobie budowania narracji sprawia że książka staje się intermedialnym komentarzem do kultury i sposobem na jej utrwalenie.

Słowa kluczowe: George Mackay Brown; An Orkney Tapestry; funkcje przewodnika; kolaż literacki; fragmentacja; intermedialność. 